\title{
Value orientations of students as the basis of the motivation to pursue higher education
}

\author{
Yulia Yuzhakova ${ }^{1}$, Liliya Polyakova ${ }^{1, *}$, and Ludmila Antropova ${ }^{1}$ \\ ${ }^{1}$ Nosov Magnitogorsk State Technical University, 455000, 38 Lenin Ave, Magnitogorsk, Russia
}

\begin{abstract}
The paper presents an attempt to explore value orientations of students of technical university on the terminal and instrumental levels aiming to determine their motivation to receive higher technical education. The results of the study can be used in the process of education.
\end{abstract}

\section{Introduction}

In contemporary Russia, higher education is regarded as one of the main factors of scientific, economic and social progress. This approach requires a large-scale reform of the entire system of higher education in Russia. This process has started and is being developed in varying degree of success. Universities update their curricula and programmes, teachers upgrade their skills and try to meet the new requirements. However, this is only one side of the coin. Speaking about the reform of education and progress, we often forget about the people who should receive education in the new reformed system, i.e. about students. Whether they are ready to learn in a new way? Do they have enough motivation for selfdevelopment and the development of the country? What are their values?

The above questions formed the basis of our study.

The relevance of the work stems from the development of the economic, social, educational environment in Russia: the living conditions in the country are changing, the relationships within the Russian society are changing as well, the system of higher education is being transformed, and a new generation of students enters the universities. This study aims to determine the value orientations of the new generation of students in the new circumstances, in order to evaluate their motivation to pursue higher education, which in its turn can help finding the methods of attracting better students to the university and maintaining their interest in studying throughout their period of education.

The aim of our research is to identify and analyze the value orientations of modern students, as the basis of their motivation to pursue higher education. The research on academic motivation and the system of students' value orientations also allow us to monitor the changes in the public's attitudes towards higher vocational education under the influence of the present socio-economic situation.

The problems of values and value orientations are studied in the context of Philosophy, Sociology, and Psychology. From the point of view of Psychology, value orientations

\footnotetext{
* Corresponding author: lilitmgn@mail.ru
} 
represent the reflections of values in human consciousness, which are recognized by $\mathrm{him} /$ her as strategic life goals and common worldview orientations.

Value orientations are the result of socialization, the result of assimilation social ideals, requirements, and assessments. This is one of the most stable characteristics of personality. In modern psychology values are usually treated as an aspect of motivation. Many Russian scientists (N. A. Buravleva [1], Z. S. Mamedova [2, 3], L. G. Zhdanova [4], N.N. Shenceva [5]) study the problem of values in close relation to the motivation sphere: when one knows human values, one can figure out and understand his/her motivation.

Our focus of research is the psychological-pedagogical aspect of the study of value orientations, which are one of the main units in the personality structure and define a person's attitude to the environment and, to some extent, determine the motivation of his/her behavior.

\section{Research Methods}

One of the earliest classifications of values was proposed by Gordon Allport [6]. According to this classification, there are six types of human value orientations. Every person possesses these orientations to a varying degree, but in different proportions. Depending on the leading value orientations, the person's type of personality can be defined. G. Allport allocates 6 personality types:

1. Theoretical type: places emphasis on rational thinking and the search for truth, takes interest in basic sciences.

2. Economical type: asserts the priority of the practical usefulness and benefit, the main value is money.

3. Aesthetic type: finds a steady interest in the aesthetic side of life; appreciates everything that is sublime and wonderful; the form is important, rather than the content; has the opinion that "beauty will save the world".

4. Social type: pays much attention to human relationships: love, friendship, loyalty, etc.

5. Political style: seeks to gain power, glory, fame and influence.

6. Religious type: attaches paramount importance to following a certain ideal, the system of views, faith.

According to Milton Rokeach [7], the author of, probably, the most popular research technique of value orientations, the values represent a form of a strong belief that a certain goal or a way of behavior and existence is preferable to any other goal and a mode of existence. Accordingly, the scientist distinguishes two classes of values: terminal and instrumental.

- Terminal values are core target values that a person perceives as the final aim of his/her existence, the aim one should pursue form a personal and social standpoints. These objectives are characterized by considerable stability and conservatism. This group includes such values as, a happy family life, love, friendship, health, etc.

- Instrumental values are values-means which have more specific behavioral orientation, aimed at the final target. Unlike terminal values, the instrumental values are more mobile and are subject to change. They include self-control, strong will, honesty, intelligence, efficiency, accuracy, etc.

In our work we used, probably, the most popular research technique for value orientations developed by Milton Rokeach.

For a self-analysis, two lists of 18 values are offered to a testee: list A (values-goals) and list B (values-means). Both lists are in alphabetical order. The testee should assign a certain rank number to each value listed corresponding to the importance he/she attributes to the value in his/her own life compared to other values (there may be alterations if necessary). Ranking the values for each of the lists, one can ask oneself a question: "To 
what extent is this value important and significant for me, to which extent do I want to implement it in my life?" The most important value is assigned to number 1, etc., the least significant one will be with the number 18 . These ranks of values, distributed by the subjects, reflect the importance of each value. It is important not to forget that in $\mathrm{M}$. Rokich's questionnaire (see Table 1) the scales have the reverse effect: the lower the rank, the higher the relevance of the value is for the respondent; and vice versa: the higher the rank, the lower the significance of the value is.

Table 1. M. Rokich's Questionnaire.

\begin{tabular}{|c|c|c|c|}
\hline Terminal values & rank & Instrumental values & rank \\
\hline $\begin{array}{l}\text { 1. Active stirring life (fulfilment } \\
\text { and emotional saturation of life) }\end{array}$ & & $\begin{array}{l}\text { 1. Accuracy (tidiness, the ability } \\
\text { to keep things in order, conduct } \\
\text { the affairs precisely) }\end{array}$ & \\
\hline $\begin{array}{l}\text { 2. Life wisdom (maturity of } \\
\text { judgments and common sense } \\
\text { achieved through life experience) }\end{array}$ & & $\begin{array}{l}\text { 2. Good breeding (good manners, } \\
\text { ability to behave oneself) }\end{array}$ & \\
\hline 3. Health (physical and mental) & & $\begin{array}{l}3 . \quad \text { High aspirations } \\
\text { requirements of life and high } \\
\text { ambitions) }\end{array}$ & \\
\hline 4. Interesting work & & $\begin{array}{l}\text { 4. Cheerfulness (optimism, sense } \\
\text { of humour) }\end{array}$ & \\
\hline $\begin{array}{l}\text { 5. The beauty of nature and art } \\
\text { (the experience of beauty in } \\
\text { nature and art) }\end{array}$ & & 5. Sense of duty (discipline) & \\
\hline $\begin{array}{l}\text { 6. Love (spiritual and physical } \\
\text { intimacy with your beloved) }\end{array}$ & & $\begin{array}{l}\text { 6. Independence (the ability to act } \\
\text { independently, resolutely) }\end{array}$ & \\
\hline $\begin{array}{l}\text { 7. Financially secured life (lack of } \\
\text { financial problems) }\end{array}$ & & $\begin{array}{l}\text { 7. The intransigence of the } \\
\text { weaknesses in ourselves and } \\
\text { others }\end{array}$ & \\
\hline $\begin{array}{l}\text { 8. The presence of good and loyal } \\
\text { friends }\end{array}$ & & $\begin{array}{l}\text { 8. Education (the scope of } \\
\text { knowledge, high cultural level) }\end{array}$ & \\
\hline $\begin{array}{l}\text { 9. Public recognition (respect by } \\
\text { your circle, staff, colleagues) }\end{array}$ & & $\begin{array}{l}\text { 9. Responsibility (a sense of duty, } \\
\text { the ability to keep one's word) }\end{array}$ & \\
\hline $\begin{array}{l}\text { 10. Cognition (the ability to } \\
\text { expand your education, broaden } \\
\text { your horizons, knowledge of } \\
\text { general culture, intellectual } \\
\text { development) }\end{array}$ & & $\begin{array}{l}\text { 10. Rationalism (ability to think } \\
\text { sensibly and logically, make } \\
\text { sound, rational decisions) }\end{array}$ & \\
\hline $\begin{array}{l}\text { 11. Productive life (the fullest } \\
\text { possible use of one's capabilities, } \\
\text { strengths and abilities) }\end{array}$ & & $\begin{array}{l}\text { 11. Self-control (self-restraint, } \\
\text { self-discipline) }\end{array}$ & \\
\hline $\begin{array}{l}12 . \quad \text { Development } \quad \text { (self- } \\
\text { improvement, continuous physical } \\
\text { and spiritual perfection) }\end{array}$ & & $\begin{array}{l}\text { 12. Courage in defending your } \\
\text { opinions }\end{array}$ & \\
\hline $\begin{array}{l}\text { 13. Freedom (self-sufficiency, } \\
\text { independence of judgments and } \\
\text { actions) }\end{array}$ & & $\begin{array}{l}\text { 13. Firm will (the ability to insist } \\
\text { on your own, not to give up facing } \\
\text { difficulties) (considerateness) }\end{array}$ & \\
\hline 14. A happy family life & & $\begin{array}{l}\text { 14. Tolerance (for the views and } \\
\text { opinions of others, the ability to } \\
\text { forgive mistakes and fallacies of } \\
\text { others) }\end{array}$ & \\
\hline
\end{tabular}




\begin{tabular}{|l|l|l|l|}
$\begin{array}{l}\text { 15. The happiness of others (well- } \\
\text { being, development and } \\
\text { improvement of other people, } \\
\text { nation, mankind in general) }\end{array}$ & $\begin{array}{l}15 . \text { Honesty (truthfulness, } \\
\text { sincerity) }\end{array}$ & \\
\hline $\begin{array}{l}\text { 16. Creativity (the ability to be } \\
\text { engaged in creative work) }\end{array}$ & 16. Responsiveness & $\begin{array}{l}\text { 17. Open-mindedness (the ability } \\
\text { to understand the other person's } \\
\text { point of view, respect the different } \\
\text { tastes, customs, habits) }\end{array}$ & \\
\hline $\begin{array}{l}17 . \quad \text { Self-confidence (inner } \\
\text { harmony, freedom from internal } \\
\text { contradictions or doubts) }\end{array}$ & $\begin{array}{l}\text { 18. Efficiency in business } \\
\text { (diligence, productivity in work) }\end{array}$ & \\
\hline $\begin{array}{l}\text { 18. Amusements (enjoyable, } \\
\text { relaxed pastime, lack of } \\
\text { responsibilities, entertainment) }\end{array}$ &
\end{tabular}

The individual hierarchy of values obtained from the research can be divided into three equal groups: (1) preferred, significant values (ranks from 1 to 6); (2) indifferent, meaningless (7-12); (3) rejected, insignificant (13-18 rank of hierarchy).

\section{Discussion}

Our survey involved 65 first- and second-year students of the Institutes of: Economics and Management; Metallurgy, Machine Building and Metal Treatment; Natural Sciences and Standardization of Nosov Magnitogorsk State Technical University, Russia.

In accordance with the recruited average score the following lists of values and priorities of students were compiled (see Table 2).

Table 2. The results of the survey.

\begin{tabular}{|c|c|c|c|}
\hline Terminal values & $\begin{array}{c}\text { average } \\
\text { score }\end{array}$ & Instrumental values & $\begin{array}{c}\text { average } \\
\text { score }\end{array}$ \\
\hline 1. Health & 2.35 & 1. Education & 4.92 \\
\hline 2. Friends & 5.55 & 2. Responsibility & 7.09 \\
\hline 3. Self confidence & 6.15 & 3. Good manners & 7.11 \\
\hline 4. Love & 6.23 & 4. Independence & 7.12 \\
\hline 5. Financially secured life & 7.28 & 5. Cheerfulness & 7.69 \\
\hline 6. Interesting work & 7.78 & 6. Strong will & 8.28 \\
\hline 7. Freedom & 7.89 & 7. Self control & 8.53 \\
\hline 8. Active life & 8.4 & 8. Courage in defending one's & 8.95 \\
& & views & \\
\hline 9. Happy married life & 8.82 & 9. Honesty & 8.95. \\
\hline 10. Life wisdom & 10.72 & 10. Accuracy & 9.75. \\
\hline 11. Development & 10.9 & 11. Efficiency in business & 10.25. \\
\hline 12. Knowledge & 11.8 & 12. Open mindedness & 10.28 \\
\hline 13. Social recognition & 12.03 & 13. Sense of duty & 10.32 \\
\hline 14. Productive life & 12.03 & 14. Tolerance & 10.49 \\
\hline 15. Entertainment & 13.37 & 15. Rationalism & 10.6 \\
\hline 16. Happiness of others & 13.65 & 16. Responsiveness & 12.38 \\
\hline 17. Creative work & 13.68 & 17. High demands & 13.51 \\
\hline 18. Beauty & 13.86 & 18. Intransigence & 14.25 \\
\hline
\end{tabular}

For the analysis of obtained data Allport's theory of value orientation was used. A 
survey of students indicates the predominance of the economic and social areas of student's value orientation. When analyzing the values-goals one can clearly see the students' desire to personal well-being (items 1-6 express socio-economic orientation): interesting work guarantees financially- secured life, self-confidence, but, of course, you cannot have a productive life without friends or love. The sole guarantee that you will implement this programme is health; it is ranked first among the priority values of students.

Items 7-12 express the theoretical orientation of students that took the second place respectively. The only exception is the 9 item "happy family life". (Students are aware of the importance of the institution of the family, but it is not the main indicator of success in life for them.)

The last group of values (items 13 -18) combine the political and aesthetic orientation. Moreover, aesthetic orientation (creativity, beauty) occupies the last place; these concepts represent the lowest value for students.

\section{Conclusion}

Thus, at this stage, the most valuable for students is personal well-being, followed by scientific and rational approach to life, and public recognition, beauty and harmony.

Personal well-being is a universal value, which takes a leading position at any period of life, in any social environment. For this survey characteristic distinguishing feature is the fact that the scientific and rational approach to life (theoretical focus) ranks second in contrast to aesthetic orientation, which occupies the last place. In our view, this result indicates the general orientation of the technical university students to science, scientific and rational approach to life.

Analyzing values-means, it can be concluded that the students realize the importance of higher education, have strong views on entering the university (education ranks first in the list B). Students appreciate such qualities as responsibility and good breeding, they are aimed at pursuing their objectives, and obtaining the necessary knowledge (this is evidenced by quite high values-means as the firm will and self-control, courage in defending one's views).

In educational work teachers should pay attention to the development of such qualities of students as accuracy (rank10) and sense of duty (rank13).

Modern students have a rather realistic view of life, they are healthy pragmatists (evidenced by 17th rank of "high demands"). But on the other hand, the students are rather indifferent to: "sensitivity" and "intransigence", these occupy the last places in their scale of values.

Compared with the results, obtained in the survey among the students of the secondary school, in this survey we can observe a more balanced students' view of life, the development of independence and self-control.

\section{References}

1. N. A. Buravleva, Vestnik TGPU, 6 (2010)

2. Zh. S. Mamedova, Russian Society: Civilizational Horizons of Transformation, 1 (2004)

3. Zh. S. Mamedova, Humanitarian and Socio-economic Sciences, Special Edition of Pedagogy, 6 (2006)

4. L. G. Zhdanova, Some features of the motivation of students. International Correspondence Scientific and Practical Conference "Pedagogical and Psychological Sciences: Modern Trends" (Siberian Association of Consultants, Novosibirsk, 2012) 
5. N. N. Shenceva, Socio-psychological determinants of student achievement motivation: dis. ... cand. psychol. science (Moscow, 2006)

6. G. Allport, Personality in Psychology (KSP+, Moscow; YUventa, SPb, 1998)

7. M. Rokeach, The nature of human values (New York, 1973) 